Bergle, it was collected and sent for inspection to Ehrenberg, and results of great scientific value accrued. Fad our great philosophic narturalist not been there, this dust might still have fallen on ships to the present day, been swept away as a nuisance, and unrecognised as of any possible interest. That errant species must frequently visit vessels was shown me on a voyage to the East a few years ago, Thus, in the early part of September, in about lat. $12^{\circ} \mathrm{N}$, and long. $26^{\circ} \mathrm{W}$, a dove few on board, which, after resting for a short time, again pursued its journey. In about lat. $9^{\circ} \mathrm{N}$. and long. $25^{\circ} \mathrm{W}$. a moth, apparentiy S. conm wolyuli, reached the vessel just before the arrival of a squall. In reply to my inquiries, both the officers and crew stated that these were simply very common occurrences.

I think we may feel confident that most vessels sailing this course meet frequently with like objects, and the interest would be increased by finding whether the same were observed by vessels still further from the nearest land. Could some means be devised for obtaining records of these migratory species, or could some large shipowner be induced to have the same caretully recorded in the log-books kept on board his vessels, I feel little doubt that we should be astonished by the number and constancy of these wanderers from other lands. The entry in the log book would ensure the date and approximate latitude and longitude which would $b$ ? necessary factors in dealing with this biological question, and would doubtless bear further proof to Mr. Darwin's view of colonisation by chance or occasional visitants.

So much might be done by some of our present means of unendowed research that it seems weary waiting for the day when a broader education will tend to induce our sailors to reap that abundant harvest of scientific information which they so constantly lave the means of acquiring. There is surely some branch of science which might be indebted to every vessel that sails from this country on a foreign voyage, could the pre. liminaxy information and impetus for inquiry be given to the offcers or crew. I believe the "Religious Tract," or some kindred society, provides many of our vessels with devotional literature; could not our learned societies also compile and provide some scientific works and questions for solution which might be placed in the hands of our sailors thus affording a pleastre for a long yoyage, and producing effects to be appreciated by science at home?

We should not expect the results of a "Challenger Expe. dition," but then Government outlays for that purpose are sometines few and far between.

Strcathara Cottage, Bucclench Road, West Duwich

\section{Murænopsis tridactyla}

Wrtre reference to Mr. Kent's letter in your last number (p. 6o), I beg leave to point out to you that it is very doubtfu, according to the best authorities, whether the soncalled Muranopis tridactyla is even stecifically different from Anptizin atwis means (i.e. the two-toed form of the same amimal). Of the latter this Society have had several living specimens in their collection. One of them (parchased December 6,1870 ) is still living in the Society's Gardens,

Zoulogical Society of London

\section{Mardened Glass}

TYTE account of hardened and malleable glass given in NATUzi, vol. xi. p. 474 , interested me greatly.

It seems hardly possible that a change in the molecular constitution of glass can take place without affecting its optical properties. May not this glass, therefore, possess refractive and dispersive power's unlike those of the kind usually employed in lonses? If it can be made of sufficient purity and is found to have a higher refractive power, it will enable us to make thinner lenses with smaller curves, thus contributing to the further im. provement of optical instruments.

Jacksonville, Illinois, U.S.A., May 6

\section{Yorkshire Exhibition "Guide"}

Wiux you kindly allow me, as a member of the Science Com* mittee of the Yorkshire Exhibition of Arts and Manufactures, beld at Leeds, to point out that the Yorkshire "Guide" referred in NATURe, vol, xii, p. 76 , is entirely an unoficial publication. No competent member of the Committee was applied to for information respecting palladium or any other exhibit. The frst intimation the Committee had of the wild statements contained in the "Guide" was received from a member who purchased a copy in the usual way, and immediate steps were taken to secure that more trustworthy information should be contained in kiture editions of the "Guide," unofficial though it be. You will, I think, see that it is rather hard that the Committee should, as by inference they may be, be made responsible for the staternents you indicate, and will, I hope, give me space for this repudiation of them.

\section{H. Pocklingron}

\section{Primroses and Cowslips}

IN answer to Mr. J. J. Murphy's inquiry in NATUR of May I3 (vol. xil. p. 34) I beg to state that the locality in which, as far as I am aware, no primroses are found, is formed by the outcrop of the chalk in the south of Cambridgeshire and north of Hertfordshire, and is bomded or the north and south by the outcrop of the chalk marl and the edge of the London Basin, and east and west by the Great Eastern and Great Northern main lines; it is, from the nature of the underlying beds, very dry. I have always thought, but perhaps without foundation, that primroses are not generally found in the districts in which cowslips are common, and vice verste, and Mr. Murphy's remark seems to bear out this.

I have not noticed any instance of the removal of the ovules of cowslips by birds; and even primroses, in other parts of the garden than those frst attacked, have been left untouched.

Odsey, near Royston, Herts

H. GEORGE FURDHAM

\section{OUR ASTRONOATCAL COLUMN}

THE MELBOURNe CATALOGUT.-We have received the "First Melbourne General Catalogue" of stars, which is founded upon the observations taken with the Transit Circle under the direction of Mr. Ellery, the Government Astronomer, at the New Observatory of Melbourne, between the middle of the year 1863 and the end of 1870 . It has been reduced and prepared for publication by $\mathrm{Mr}$. E. J. White, the first assistant, from the materials printed in vols, ii. iii, and iv of the Melbowme Observations. Vol. i. contained a catalogue of 546 stars resulting from the meridian observations taken previous to the removal of the Observatory to its present site, and called the "Williamstown Catalogue:" in the new publication we have the positions for the beginning of 1870 , of 1227 stars, with few exceptions observed at least three times, and accompanied by the terms of precession to the third order, proper motions, and Bessel's reduction-constants (as in the British Association Catalogue), with the synonyms in Lacaille, Piazi, Brisbane, and Johnson. Great care appears to have been taken in calculating the precessions from the mean year of observation to the epoch of the catalogue, and a detaled account of the process employed is given in the introduction. The proper motions of the stars have also been discussed Where the means were available, the more uncertain results being distinguished from those possessing greater claim to acceptance by enclosure in parentheses.

Many of the most interesting stars of the southern heavens are included in this Catalogue, and we note that the remarkable one $E$ Indi has not been overlooked. In this case the recent Melbourne observations, as compared with Jacobs' at Madras in 1852 , assign an annual proper motion of $4^{\prime \prime} \cdot 58$ in arciof great circle, thus quite confirming values previously obtained from less reliable data. We hope that at no distant period an attempt will be made to determine the parallax of this star. Large proper motion is indicated for the stars B. A. C. $57 \mathrm{I} 9$, Arz, and 7816 . Indi; but on comparing the Melbourne positions with those in Gilliss's Santiago Catalogue, in the Washington volume of observations for 1868, not mentioned by $\mathrm{Mr}$. White amongst the authorities he had consulted, it is not confirmed in either case.

"The "First Melbourne Catalogue" is a handsome specimen of typography from the Government Printing Office. It must form an essential work of reference for every southern astronomer, who has now, with the "Cape 